
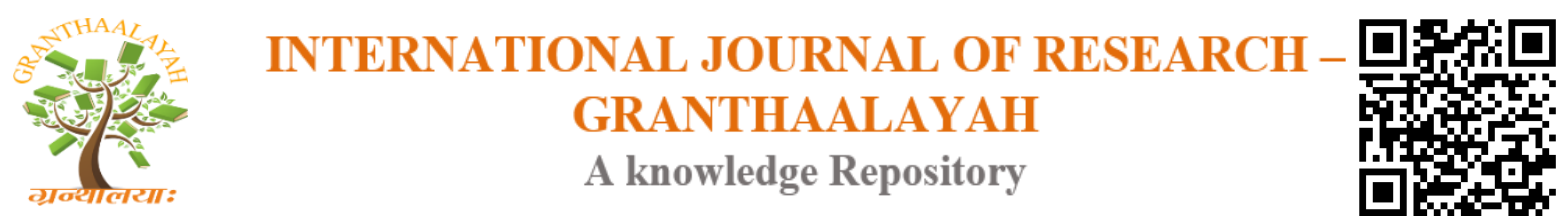

Science

\title{
STUDY OF CLINICAL FEATURES AND EPIDEMIOLOGY OF COMPLICATED VIVAX MALARIA
}

\author{
Dr. Arvind Mathur ${ }^{1}$, Dr. Mohit Kackar ${ }^{2}$, Dr. Indu Thanvi ${ }^{3}$, Dr. Harish Agarwal ${ }^{4}$ \\ ${ }^{1}$ Professor and Head Department of Medicine, Dr SN Medical College, India \\ ${ }^{2}$ Medical Officer, MDM Hospital, India \\ ${ }^{3}$ Assistant Professor Medicine, Dr SN Medical College, India \\ ${ }^{4}$ JS Medicine, Dr SN Medical College, India
}

\begin{abstract}
Severe and complicated malaria is defined by the World Health Organization Malaria Action Programme in June 19851 as the presence of one or more of the following conditions in a slide confirmed diagnosed case of malaria cerebral malaria, severe anemia, renal failure, pulmonary edema or adult respiratory distress syndrome, hypoglycemia, circulatory collapse or shock, spontaneous bleeding, repeated generalized convulsions, acidemia or acidosis, macroscopic hemoglobinuria, impairment of consciousness less marked than unarousable coma, hyperparasitemia, jaundice, hyperpyrexia, and the presence of complicating or associated infections. However, severe anemia and thrombocytopenia that causes bleeding diatesis is produced by hemolysis, reduced cell deformity of parasitized and non-parasitized erythrocytes, increased splenic clearance, reduction of platelet survival, decreased platelet production, and increased splenic uptake of platelets. Though these changes can be produced by P. vivax and P. falciparum infection yet the complicated malaria has commonly been associated with P. falciparum infections.
\end{abstract}

Keywords: Study; Clinical Features; Epidemiology.

Cite This Article: Dr. Arvind Mathur, Dr. Mohit Kackar, Dr. Indu Thanvi, and Dr. Harish Agarwal. (2019). "STUDY OF CLINICAL FEATURES AND EPIDEMIOLOGY OF COMPLICATED VIVAX MALARIA." International Journal of Research - Granthaalayah, 7(9), 47-51. https://doi.org/10.29121/granthaalayah.v7.i9.2019.556

\section{Introduction}

Vivax malaria has been commonly considered benign devoid of these complications. However, there have been reports of complications associated with Vivax malaria ${ }^{234} \mathrm{P}$. vivax complications are both sequestration-related and nonsequestration-related ${ }^{5}$ including cerebral malaria, renal failure, circulatory collapse, severe anemia, hemoglobinurea, abnormal bleeding, ARDS, and jaundice. 
In view of higher incidence of vivax malaria and recent reports of complications associated with it; there is a need to study the epidemiology of it. Thus a cross sectional study has been carried out to find out the clinical features and epidemiology of complications related to P.vivax malaria in Western Rajasthan.

\begin{tabular}{|c|c|}
\hline \multicolumn{2}{|r|}{ Indicators of severe malaria } \\
\hline Manifestation & Features \\
\hline \multicolumn{2}{|c|}{ Initial World Health Organization criteria from $1990^{6}$} \\
\hline Cerebral malaria & $\begin{array}{l}\text { Unrousable coma not attributable to any other cause, with a } \\
\text { Glasgow Coma Scale score } \leq 9 \text {. Coma should persist for at least } \\
30 \text { min after a generalized convulsion }\end{array}$ \\
\hline Severe anemia & $\begin{array}{l}\text { Hematocrit }<15 \% \text { or hemoglobin }<50 \mathrm{~g} / \mathrm{l} \text { in the presence of } \\
\text { parasite count }>10000 / \mu 1\end{array}$ \\
\hline Renal failure & $\begin{array}{l}\text { Urine output }<400 \mathrm{ml} / 24 \text { hours in adults }(<12 \mathrm{ml} / \mathrm{kg} / 24 \mathrm{hours} \\
\text { in children) and a serum creatinine }>265 \mu \mathrm{mol} / \mathrm{l}(>3.0 \mathrm{mg} / \mathrm{dl}) \\
\text { despite adequate volume repletion }\end{array}$ \\
\hline $\begin{array}{l}\text { Pulmonary edema and acute } \\
\text { respiratory distress syndrome }\end{array}$ & $\begin{array}{l}\text { The acute lung injury score is calculated on the basis of } \\
\text { radiographic densities, severity of hypoxemia, and positive } \\
\text { end-expiratory pressure }\end{array}$ \\
\hline Hypoglycemia & Whole blood glucose concentration $<2.2 \mathrm{mmol} / \mathrm{l}(<40 \mathrm{mg} / \mathrm{dl})$ \\
\hline \begin{tabular}{|ll|l}
$\begin{array}{l}\text { Circulatory collapse (algid } \\
\text { malaria) }\end{array}$ & \\
\end{tabular} & \begin{tabular}{|l|} 
Systolic blood pressure $<70 \mathrm{mmHg}$ in patients $>5$ years of age \\
$(<50 \mathrm{mmHg}$ in children aged $1-5$ years $)$, with cold clammy skin \\
or a core-skin temperature difference $>10^{\circ} \mathrm{C}$
\end{tabular} \\
\hline $\begin{array}{l}\text { Abnormal bleeding and/or } \\
\text { disseminated intravascular } \\
\text { coagulation }\end{array}$ & $\begin{array}{l}\text { Spontaneous bleeding from gums, nose, gastrointestinal tract, or } \\
\text { laboratory evidence of disseminated intravascular coagulation }\end{array}$ \\
\hline $\begin{array}{l}\text { Repeatedgeneralized } \\
\text { convulsions }\end{array}$ & $\geq 3$ convulsions observed within 24 hours \\
\hline Acidemia/acidosis & Arterial $\mathrm{pH}<7.25$ or acidosis (plasma bicarbonate $<15 \mathrm{mmol} / \mathrm{l}$ ) \\
\hline Macroscopic hemoglobinuria $\begin{array}{ll}\mathrm{H} \\
\mathrm{d}\end{array}$ & \begin{tabular}{|l} 
Hemolysis not secondary to glucose-6-phosphate \\
dehydrogenase deficiency
\end{tabular} \\
\hline \multicolumn{2}{|c|}{ Added World Health Organization criteria from $2000^{7}$} \\
\hline Impaired consciousness & Rousable mental condition \\
\hline Hyperparasitemia & $\begin{array}{l}>5 \% \text { parasitized erythrocytes or }>250000 \text { parasites } / \mu 1 \text { (in } \\
\text { nonimmune individuals) }\end{array}$ \\
\hline Hyperpyrexia & Core body temperature $>40^{\circ} \mathrm{C}$ \\
\hline Hyperbilirubinemia & Total bilirubin $>43 \mu \mathrm{mol} / \mathrm{l}(>2.5 \mathrm{mg} / \mathrm{dl})$ \\
\hline
\end{tabular}




\section{Aims and Objectives}

1) To study clinical manifestations and various complications associated with patients of malaria.

2) To study complications associated with P. vivax malaria and related various risk factors.

\section{Study Design}

The present study was a cross-sectional hospital-based survey in patients of malaria.

The study was conducted in patients admitted at attached hospitals of Dr. S. N. Medical College, Jodhpur.

Selected individuals were examined and findings recorded in pre designed proforma.

Various investigations like routine blood counts including HB, (TLC), (DLC), platelet counts and peripheral blood film, chemistry (liver function test, renal function test, blood sugar \& serum electrolyte), HbsAg and hepatitis C marker urine(albumin, pus cells, RBC)specific tests for diagnosis of malaria like MPQBC \& MPSTRIP was done. Radiological investigation like Chest Xray,were performed as required The duration of illness and the outcome after treatment was recorded.

Criteria for selection Patients with positive peripheral blood film for malaria parasite and/or positive MP-QBC/ MPSTRIP optimal test and one of the following criteria were included in study.

Table 1: complicated malaria

\begin{tabular}{|l|l|l|l|l|l|l|}
\hline & \multicolumn{3}{|c|}{ FALCIPARUM \&MIXED } & \multicolumn{3}{c|}{$\begin{array}{c}\text { Vivax } \\
\text { N=71 }\end{array}$} \\
\hline \multicolumn{1}{|c|}{ Criteria } & Male & Female & \multicolumn{1}{|c|}{ Total } & Male & Female & Total \\
\hline ANEMIA & 4 & 2 & $6(8.4 \%)$ & 2 & & $2(2.5 \%)$ \\
\hline RENAL FALIURE & 6 & 3 & $9(13 \%)$ & 4 & 2 & $6(8 \%)$ \\
\hline PUL OEDEMA & 1 & & $1(1.4 \%)$ & 2 & & $2(2.5 \%)$ \\
\hline HYPOGLYCEMIA & 2 & 0 & $2(2.8 \%)$ & 1 & 0 & $1(1.2 \%)$ \\
\hline HYPOTENSION & 2 & 1 & $3(4.2 \%)$ & 2 & 1 & $3(3.8 \%)$ \\
\hline $\begin{array}{l}\text { ABNORMAL } \\
\text { BLEDING }\end{array}$ & 6 & 2 & $8(11.2 \%)$ & 2 & 1 & $3(3.8 \%)$ \\
\hline $\begin{array}{l}\text { HYPERBILIRU } \\
\text { BINEMIA }\end{array}$ & 12 & 5 & $17(24 \%)$ & 6 & 3 & $9(11.4 \%) *$ \\
\hline HYPER PYREXIA & 6 & 2 & $8(11.2 \%)$ & 5 & 2 & $7(8.9 \%)$ \\
\hline CEREBRAL MALARIA & 5 & 4 & $9(12.7 \%)$ & 2 & 1 & $3(3.7 \%) *$ \\
\hline
\end{tabular}

Table - shows the Incidence of inclusion criteria for severe and complicated malaria Severe anemia is seen in $2.5 \%$ cases of vivax as compared to falciparum \& mixed in which severe malaria seen in $8.4 \%$ cases. pulmonary oedema is seen more in vivax $(2.5 \%)$ as compared to (1.4\%) in 
falciparum \& mixed. Incidence of hypoglycemia is seen in $1.2 \%$ cases of vivax as compared to $2.8 \%$ in falciparum \& mixed, hypotension is seen in $3.8 \%$ cases of vivax as compared to $4.2 \%$ in falciparum \& mixed, hyper pyrexia is seen in $8.9 \%$ cases of vivax as compared to $11.2 \%$ in falciparum \& mixed .Renal failure, cerebral malaria, $\mathrm{p}<.05$ hyper bilirubinemia $\mathrm{p}<.05$ are all observed in vivax malaria $(8 \%, 3.7 \%, 11.4 \%)$ but in less incidence than falciparum \& $\operatorname{mixed}(13 \%, 12 \%, 24 \%)$.

\section{Summary and Conclusions}

- Results from our study clearly indicated that complications like cerebral malaria, renal failure, ARDS circulatory collapse, hypoglycemia, severe anemia, jaundice and abnormal bleeding, are not uncommon in pvivax malaria.

- Inspite of low incidence of complication than falciparum and mixed mortality have been reported in vivax malaria.

Bar Graph Showing Difference in Complication Between Vivax and Malaria

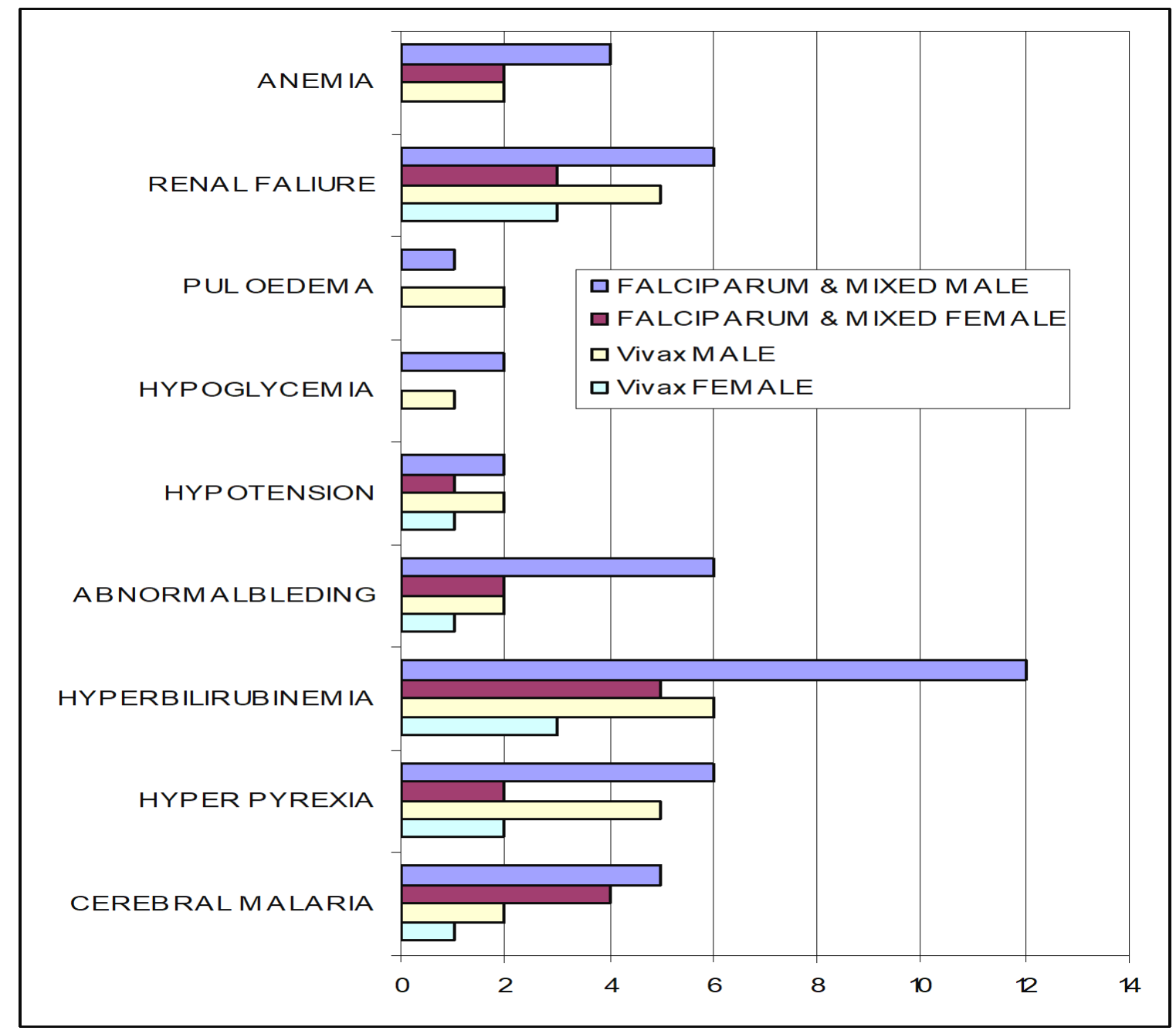


Abstract-The study was carried out on all diagnosed cases of malaria admitted in attached hospitals of Dr. S.N Medical College Jodhpur. Total number of 150 malaria patients, out of them $53 \%$ were vivax and $47 \%$ were falciparum/ mixed., This study implicates that incidence of complicated vivax malaria is increasing, previously it was thought that Pvivax infection is benign and uncomplicated but from last few years there are various reports suggesting that incidence of complicated $\mathrm{p}$ vivax malaria is rising thus we should be vigilant for the various complications associated with $\mathrm{P}$ vivax malaria and treating vivax malaria on lines of complicated falciparum malaria as given by WHO.

\section{References}

[1] WHO Malaria Action Programme. Severe and complicated malaria. Trans Roy Soc Trop Med Hyg 1986; 80 (suppl):3-50.

[2] Prakash Singh AK, Kumar NS, Saxena R. K: Acute renal failure in Plasmodium vivax malaria J Assoc Physicians India. 2005 Jul; 53:655;

[3] Beg M.A., Khan R., Baig S.M., et al. Cerebral involvement in benign tertian malaria. Am J Trop Med H2002; 67:230-233.

[4] Curlin M.E., Barat L.M., Walsh D.K., Granger D.L. Non-cardiogenic pulmonary edema during vivax malaria. Clin Infect Dis 1999; 28:1166-7.

[5] Kochar DK, Saxena V, Singh $\mathrm{N}$ et al. Plasmodium vivax malaria. Emerg Infect Dis 2005;11(1):132-134.

[6] WHO: Severe and complicated malaria. World Health Organization, Division of Control of Tropical Diseases. Trans R Soc Trop Med Hyg 1990; 84 Suppl 2: 1-65.

[7] World Health Organization. Severe falciparum malaria. Trans R Soc Trop Med Hyg. 2000; 94:3840 . 